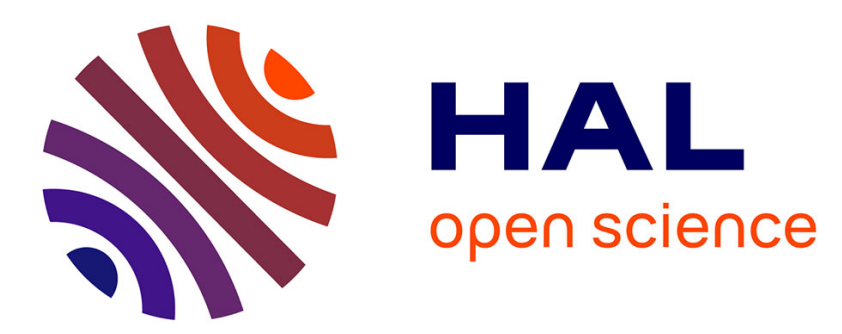

\title{
Outsourcing of urban metabolisms and its consequences: A multiscale energy flow analysis of a French port-city
}

Audrey Tanguy, Jean-Baptiste Bahers, Aristide Athanassiadis

\section{To cite this version:}

Audrey Tanguy, Jean-Baptiste Bahers, Aristide Athanassiadis. Outsourcing of urban metabolisms and its consequences: A multiscale energy flow analysis of a French port-city. Resources, Conservation and Recycling, 2020, 161, pp.104951. 10.1016/j.resconrec.2020.104951 . hal-02916847

\section{HAL Id: hal-02916847 \\ https://hal.science/hal-02916847}

Submitted on 23 Sep 2020

HAL is a multi-disciplinary open access archive for the deposit and dissemination of scientific research documents, whether they are published or not. The documents may come from teaching and research institutions in France or abroad, or from public or private research centers.
L'archive ouverte pluridisciplinaire HAL, est destinée au dépôt et à la diffusion de documents scientifiques de niveau recherche, publiés ou non, émanant des établissements d'enseignement et de recherche français ou étrangers, des laboratoires publics ou privés. 
1 Outsourcing of urban metabolisms and its consequences: a multiscale energy flow

2 analysis of a French port-city

3 Audrey Tanguy $^{1 *}$, Jean-Baptiste Bahers ${ }^{2}$, Aristide Athanassiadis ${ }^{3}$

$4 \quad{ }^{1}$ LIRIDE, Building and Civil Engineering department, Université de Sherbrooke, Sherbrooke (QC),

5 Canada, audrey.tanguy@usherbrooke.ca

$6 \quad{ }^{2}$ CNRS, Université de Nantes, UMR 6590 ESO (Spaces and societies), Nantes, France,

7 jeanbaptiste.bahers@univ-nantes.fr

8

$9 \quad{ }^{3}$ Building, Architecture and Town Planning department, Université Libre de Bruxelles, Brussels, 10 Belgium, arisatha@ulb.ac.be

11

12

*corresponding author 


\section{Abstract}

15 Outsourcing of urban metabolisms is a phenomenon that has grown exponentially over the last century.

16 It is a cause of vulnerability for cities for two main reasons. They are dependent on distant hinterlands

17 and their consumption induces global environmental impact they do not fully control. This study aims

18 to investigate these two effects of outsourcing through a single, multiscale approach to energy

19 accounting. A spatially differentiated energy flow analysis (EFA) is developed, which includes

20 indicators for dependency, embodied energy and energy losses. Applied to the case of the harbor-

21 industrial area of Saint-Nazaire, France, the results show that the global scale dominates dependency

22 and embodied energy indicators, whereas primary energy losses occur mainly at the domestic scale. The

23 local scale accounts for less than $0.1 \%$ of the energy supply and about $6 \%$ of indirect flows. The spatial

24 trajectories of some renewables (wood, biofuels, wind electricity) suggest that the energy transition

25 could decrease global dependency, but with a transfer to the domestic level, and not necessarily to the

26 local scale, without a radical change from the port's production system. Moreover, trade-offs could

27 emerge between reducing the amount of embodied energy in foreign countries and using energy losses

28 as a local secondary source, depending on the resource used to generate the losses. This study highlights

29 thus the need to link local transition policies more closely to outsourcing issues in order to allow a

30 comprehensive understanding of the possible transfers in terms of dependency and environmental

31 burdens that may occur in a transition context.

32 Keywords : energy metabolism; outsourcing; dependency; embodied energy ; energy losses ; energy

33 transition 


\section{Introduction}

One characteristic of current urban systems is their reliance on national and global hinterlands (Barles and Knoll, 2019). Cities are indeed open systems, which depend on outside territories for materials, food and energy supply as well as to process the resulting waste from urban activities (Krausmann, 2013).

While this characteristic is inherent to cities from all size and shape, the extent of this outsourcing has exploded over the last century due to an ever-increasing demand of resources to sustain urban growth (Athanassiadis et al., 2016; Kennedy et al., 2007).

In particular, the massive globalization of energy markets poses several challenges for cities. Because they only have a partial control over the supply chains, their energy security may be threatened in case of global economic and ecological crises. For example, the explosion of the nuclear power plant in Fukushima in 2011 affected for months the worldwide availability and affordability of liquefied natural gas owing to Japan's increased demand (Hayashi and Hughes, 2013). This event demonstrated, if needed, how the interdependency of national energy supplies makes cities vulnerable to changes of consumption patterns occurring in foreign countries (Verrastro and Ladislaw, 2007). Moreover, outsourcing energy supply means leaving an external environmental rucksack in the form of indirect flows (carbon, water, energy etc.), that cannot be easily managed by local authorities wishing to reduce their environmental footprint (Chen and Zhu, 2019; Wiedmann et al., 2016).

The current energy transition undertaken by many countries worldwide aims to bring about potential solutions to these problems by encouraging energy efficiency policies and a secure supply from lowcarbon energy sources (Rosales Carreón and Worrell, 2018). However, the geographical implications of this energy transition are not yet determined due to the multiplicity of the flows involved, the spatial distribution of these new resources and the heterogeneity of urban developments (Balta-Ozkan et al., 2015; Bridge et al., 2013). At the very least, these implications can be more complex than a mere reduction of the cities' energy dependence and environmental footprint. It is therefore essential to have a better understanding of the origins of current and potential future energy flows in order to formulate appropriate policy recommendations.

Because research on urban metabolism aims to provide a comprehensive understanding of urban flows' trajectories, it has been extensively used to address outsourcing-related issues. Different accounting approaches based on different definitions of the geographical systems boundaries have been developed to show various aspects of cities' outsourcing (Baynes and Wiedmann, 2012; Chavez and Ramaswami, 2013; Minx et al., 2013; Zhang et al., 2018). Territory-based approaches are particularly useful to study the effects of consumption patterns and local planning on cities' spatial imprint, i.e. the extent of dependency on resources hinterlands (Barles and Knoll, 2019; Billen et al., 2009; Krausmann, 2013). However, these studies fall short in encompassing all relevant urban flows since they don't include indirect consumptions and emissions due to urban activities occurring outside the city's boundaries 
(Galli et al., 2012; Ramaswami et al., 2011). Consumption-based and hybrid approaches integrate those flows at various levels to quantify their spatial spread (Lenzen and Peters, 2010; Wiedmann et al., 2016, 2015), compare cities' performance and metabolic profiles (Chavez and Ramaswami, 2013; Chen et al., 2020; Hu et al., 2016; J. Lin et al., 2013) or unveil key drivers of indirect emissions in urban consumption (Chen and Zhu, 2019; Jones and Kammen, 2011; Larsen and Hertwich, 2010; T. Lin et al., 2013; Minx et al., 2013).

However, in the context of transition policies, both issues of cities' dependency on hinterlands and related indirect flows have not been adequately addressed. Since substitutions of resources flows are to be expected, unintended transfers of environmental burdens and dependency from a supply chain to another and/or from a spatial scale to another may occur. Yet, dependency and indirect emissions due to imports are often considered at an aggregate level (rest of the world) and multiscale analyses of these issues are scarce. Kim and Barles (2012) mapped the supply areas of Paris' energy consumption for different types of energy carriers, but the analysis did not consider related indirect emissions. Chen and Zhu (2019) distinguished local, domestic and foreign origins of Beijing's carbon footprint, but at aggregated sectoral levels, preventing thus from analyzing differences and possible trade-offs between energy supply chains. A finer decomposition of supply chains across scales by type of flows is therefore necessary to have a complete picture of the transition's consequences (Boyer and Ramaswami, 2017).

To this end, the objective of this paper is to perform a multiscale analysis of urban outsourcing and discuss its implications within the frame of transition policies. This study takes advantage of combining spatial imprint analysis with indirect flows estimations in order to provide a decomposition of flows' origins and impact across scales. The energy metabolism of a harbor-industrial area, the Saint-Nazaire agglomeration in France, is chosen as a case study. A previous work of the authors addressed the political perspective of urban outsourcing, by identifying the nature of the power relationships between SaintNazaire and its energy-supplying hinterlands (Bahers et al., 2020). Nevertheless, it used aggregated energy indicators, especially for indirect flows. Therefore, this work intents to broaden the quantitative part of the analysis by illustrating the need to use spatially-differentiated dependency and indirect flows indicators to better understand energy transition policies. At the end, the previous political framework and the quantitative approach to energy metabolisms presented in this work are complementary and should be used in parallel to allow a better contextualization of urban policies aiming at minimizing the negative effects of outsourcing.

The article is structured as follows. First, the method section will provide more information on the accounting approach, and its application in a multiscale context. The case study will be also briefly introduced. Then, the third section will present the quantitative results on external dependency and indirect energy flows associated with Saint-Nazaire's activities. The fourth section will discuss the 
results in the light of energy transition policies. It will particularly stress insights brought by the multiscale analysis.

\section{Methods}

This section presents the extended territory-based approach applied in this study, which includes 1) a multiscale energy flow analysis (EFA) tracing flows trajectories back to their origins and 2) indirect energy flows estimations at the global, domestic and local scales. The Saint-Nazaire's case study is then detailed as wells as the data sources and main assumptions.

\subsection{Methods for material and impact accounting at the city scale}

Three main approaches exist to quantify urban metabolisms: territory-based, consumption-based and hybrid (trans-boundary) approaches (Athanassiadis et al., 2016; Chen et al., 2019). Territory-based approaches look into what comes in and out of the city, as well as what it produces and consumes (Huang et al., 2012). The most common method is material and energy flow analysis (MEFA), an accounting framework developed by a number of scientists and summarized by Eurostat (Eurostat, 2001). It uses local data, usually from different sources reporting direct emissions and resources consumption occurring within the city's boundaries. Consumption-based approaches rely most of the time on national or multi-region input-output (IO) tables, that approximate urban consumption as physical flows imported and exported at the global and/or domestic levels (Athanassiadis et al., 2016). Consumptionbased modeling does not require collection of emissions data but assumes an emission intensity for imported products to estimate indirect emissions. While more comprehensive, this modeling using IO tables often lack in geographical resolution at the city scale (Baynes and Wiedmann, 2012). Expenditure data for all economic sectors are indeed not always publicly available at the level of metropolitan statistical areas (Ramaswami et al., 2008). Moreover, the imported products cannot be traced back to their origins (Chen et al., 2019), even though this particular issue has been solved at the national level by combining multi-region IO tables with ecological network analysis (Zheng et al., 2018).

In this study, a hybrid approach which combines the accuracy of local consumption, the level of details of a material flows analysis with the comprehensiveness of life cycle-based embodied assessment is used. In carbon accounting literature, which is the most prolific on this issue, this approach is referred to as trans-boundary infrastructure, community infrastructure-based or geographic-plus infrastructure footprint since it accounts for territorial emissions plus indirect emissions of key infrastructures and food provision (Chen et al., 2019). Trade balance of non-infrastructure emissions (e.g services) are not considered, which is the main difference with the consumption-based approach (Chavez and Ramaswami, 2013; Minx et al., 2013). In a more general context of material and impact footprint analysis, hybrid approaches can refer to any methodology based on a territorial MEFA combined with either multi-region IO tables, environmentally-extended or not depending on the indicator assessed (J. Lin et al., 2013; Lin et al., 2015; Liu and Müller, 2013) or life cycle indicators (e.g. emissions intensity 
or impact factors) to account for upstream stages of the supply chains (Dittrich et al., 2012; Hillman and

139 Ramaswami, 2010; Kennedy et al., 2009; Mancini et al., 2015; Ramaswami et al., 2008).

140 Since hybrid is a rather generic term, extended territory-based approach will be used in the rest of the

141 document. Owing to the aggregated-related nature of IO tables, extended territory-based approaches

142 with life cycle indicators are particularly relevant when indirect flows associated with extraction and

143 transformation are diverse between different types of flows (Dittrich et al., 2012), which is the case for

144 energy carriers. However, limitations of the method are its labor-intensive process and the collection of

145 data from various sources that can compromise results' reliability (Chen et al., 2019). In this work, an

146 accounting method based on the use of life cycle indicators is performed and further detailed in the next

147 sub-section.

\subsection{Multiscale extended territory-based accounting method}

The extended territory-based accounting method used in this study presents two key characteristics: it is adapted to fit a multiscale energy analysis and it accounts for two indirect energy flows related to urban consumption, i.e. embodied energy consumption and energy losses. The first step consists in carry out a multiscale energy flow analysis (EFA). EFA derives directly from the MEFA method, by accounting only for technology energy (fossil fuels and renewable energy). Table 1 presents an overview of common EFA indicators. Imports and exports indicators are divided into domestic and global categories to highlight the proximity (or lack thereof) between the urban area and its hinterland. The total final energy consumption (TFEC) indicator is linked with its related indirect energy flows, i.e. embodied energy consumption and energy losses, that are generated at various spatial levels.

Table 1: Common Energy Flow Accounting (EFA) indicators and adaptation in case of a spatialization. Adapted from (Kim and Barles, 2012).

\begin{tabular}{|c|c|c|}
\hline $\begin{array}{c}\text { Common EFA } \\
\text { indicators }\end{array}$ & Definition & Multiscale EFA in this work \\
\hline $\begin{array}{l}\text { Domestic extraction to } \\
\text { processing }\end{array}$ & $\begin{array}{l}\text { Primary energy extracted within the } \\
\text { geographical boundaries of the } \\
\text { system and entering the economy to } \\
\text { be processed inside the territory }\end{array}$ & - \\
\hline $\begin{array}{l}\text { Domestic extraction to } \\
\text { exports }\end{array}$ & $\begin{array}{l}\text { Primary energy extracted within the } \\
\text { geographical boundaries of the } \\
\text { system and entering the economy to } \\
\text { be processed outside the territory }\end{array}$ & Global and domestic exports \\
\hline $\begin{array}{c}\text { Imports of processed } \\
\text { energy }\end{array}$ & $\begin{array}{l}\text { Final energy coming from another } \\
\text { socioeconomic system }\end{array}$ & \multirow{2}{*}{ Global and domestic imports } \\
\hline $\begin{array}{l}\text { Import of non-processed } \\
\text { energy }\end{array}$ & $\begin{array}{l}\text { Primary energy coming from another } \\
\text { socioeconomic system }\end{array}$ & \\
\hline $\begin{array}{c}\text { Total final energy } \\
\text { consumption (TFEC) }\end{array}$ & Energy delivered to final consumers & $\begin{array}{l}\text { Global, domestic and local } \\
\text { indirect energy flows }\end{array}$ \\
\hline $\begin{array}{l}\text { Exports of processed } \\
\text { energy }\end{array}$ & $\begin{array}{l}\text { Final energy that leaves the system to } \\
\text { another economy }\end{array}$ & Global and domestic exports \\
\hline
\end{tabular}


Exports of non-processed Primary energy that leaves the energy

Primary and final energy are accounted separately. According to the International Energy Agency (IEA) and the French statistics agency (INSEE), final energy is the energy delivered to consumers in its final form (e.g. motor gasoline) while primary energy is the energy available before any transformation occurs (like crude oil, dry natural gas, solar energy etc.) (IEA, 2017; INSEE, 2020). But while primary energy data in national statistics only account for primary energy imports and production, the EFA method accounts also for primary energy embedded in final energy imports (Kim and Barles, 2012). Estimating primary from final energy is performed with primary energy factors (PEF), which account for energy losses due to inefficiencies in transformation and transportation processes (Wilby et al., 2014). The factors used in this analysis are presented in Table A.1 in the appendices.

The second part of the analysis consists in estimating indirect energy flows related to the TFEC indicator. Energy losses derive directly from the primary energy calculations, as explained by Eq. 1:

$$
L_{!}=\sum^{\prime \prime}\left(E P_{!^{\prime \prime}}-E F_{!^{\prime \prime}}\right)=\sum^{\prime \prime}\left(E F_{!^{\prime \prime}} *\left(P E F_{!^{\prime \prime}}-\quad 1\right)\right)
$$

Where $\mathrm{L}_{\mathrm{i}}$ are the energy losses (in Joules) associated to the energy carrier $\mathrm{i}, \mathrm{EP}_{\mathrm{ij}}$ is the primary energy consumption (in Joules) of energy carrier $\mathrm{i}$ coming from flow $\mathrm{j}$, Fijis the gross final energy consumption (in Joules) of energy carrier $\mathrm{i}$ coming from flow $\mathrm{j}$ and $\mathrm{PEF}_{\mathrm{ij}}$ the primary energy factor associated to the transformation of flow $\mathrm{j}$ into flow $\mathrm{i}$. These losses are traced back at the local, domestic and global scales thanks to the information from the multiscale EFA.

Using Eq. 1, it is assumed that all the losses come from transformation processes (processing of raw natural gas, conversion of gas or coal to electricity etc.) whereas losses occur also during transportation. While this is clearly a limitation of the study, it nuanced by the fact that energy transformation is responsible for about $90 \%$ of the losses along the supply chains (Sims et al., 2007).

Indirect energy consumption refers to the energy used to produce the energy flows quantified in EFA study. It is the energy consumed for crude oil processing, for example, or for the production of solar panels. The embodied energy was obtained via the cumulative energy demand (CED) characterization method developed by Frischknecht et al. (2015) and using the ecoinvent v.3.5 database. The database contains more than 16000 interconnected processes of several economic sectors such as utilities, construction, transportation, manufacturing, and mining, allowing thus to cover most processes of the energy supply chains. The CED method differentiates between non-renewable (fossil and nuclear) and renewable (biomass, solar, wind, geothermal, water) embodied energy. Only the non-renewable energy factors were used. They are reported in Table A.1 in the appendices. It should be noted that data from 
191

the ecoinvent database are considered generic, as most modelled supply chains (except electricity's) are not specific to the French case study, which induces uncertainties in the calculations.

\subsection{Case study and data sources}

The Saint-Nazaire metropolitan area, known as the Communauté d'Agglomération de la Région Nazairienne et de son Estuaire (CARENE), is composed of ten municipalities, located at the Loire river's mouth, on the French Atlantic coast. It is a heterogeneous territory in terms of land use and functionality. Figure 1 shows that the North and North-West are dominated by forests and semi-natural areas. The South and South-East, turned towards the ocean, are highly urbanized and industrialized. Saint-Nazaire is indeed an industrial-port area consisting in a complex network of highly energyintensive industrial sites operating shipyards, steel, petrochemical and agri-fod activities (AXENNE, 2016).
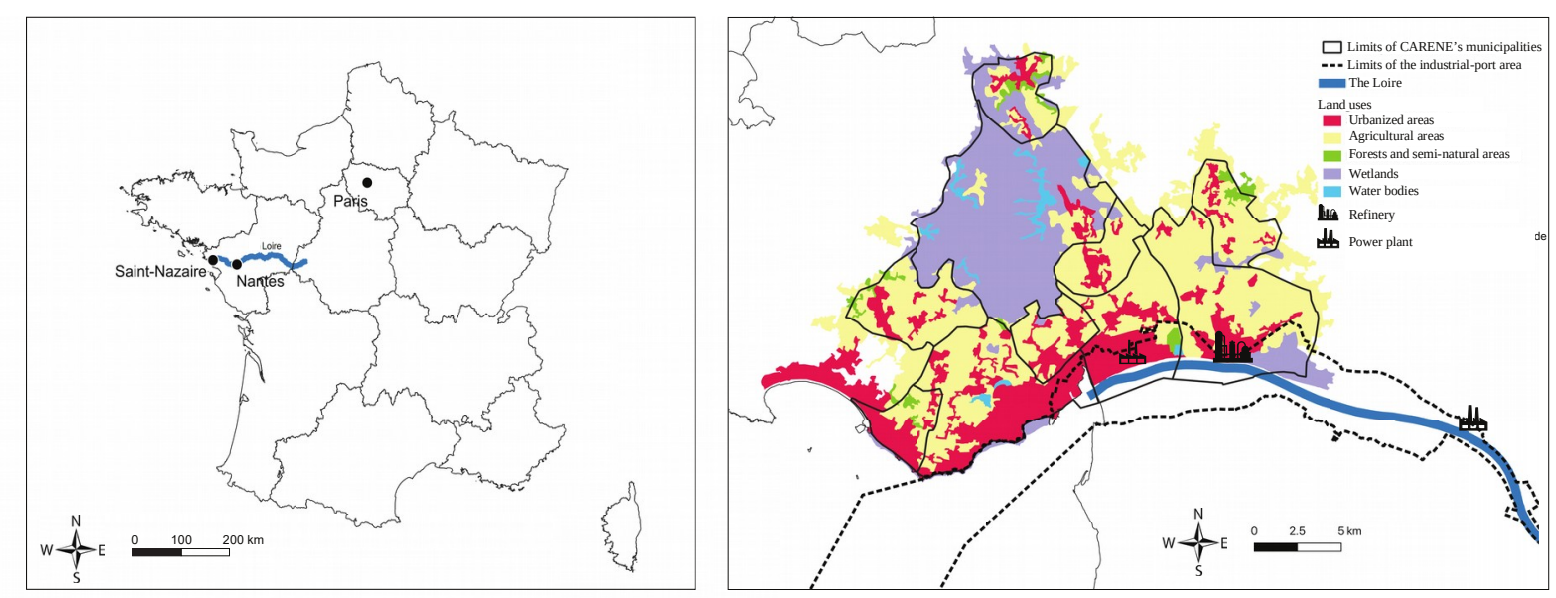

Figure 1: Geographical location of the Saint-Nazaire metropolitan area in France (left side) and spatial distribution of its land uses (right side). The port zone is spreading across three municipalities, in the South-East of the territory. (single column)

Stretching over three municipalities (Saint-Nazaire, Montoir-de-Bretagne and Donges), the port zone is home to the $2^{\text {nd }}$ largest crude oil refinery in France and to the largest methane terminal on the Atlantic coast (one of the three still operating in France) (DREAL, 2012). It provides about 12\% of the France's petroleum products supply, $2 \%$ of its natural gas supply and, overall, $10 \%$ of the France's total energy supply (DROPEC, 2016). Therefore, this territory is a logistic hub for energy flows: in 2014, they represented about two third of the port's traffic, mainly petroleum products, natural gas and coal. This makes of the CARENE an interesting case for a multiscale energy metabolism study.

The EFA includes data from the residential, tertiary, industrial and transportation (road, rail and airline) sectors. They come from several local sources which are presented in Table 2 for each flow. In Table 2, most of data sources refer to how the quantities of flows were determined for the base year (2015), except for uranium, rapeseeds and wood imports for which the sources gave information on the origins 
217 of the energy products. The total production of the refinery, estimated based on crude oil imports 218 provided by the Saint-Nazaire port authority as part of the OPTIMISME ${ }^{1}$ research project, was divided 219 among the different petroleum products using an online public report from Total.

Table 2: Data sources per energy carrier used in this study

\begin{tabular}{|c|c|c|c|c|}
\hline & Energy carriers & Sources & Data year & Type of processing \\
\hline \multirow{8}{*}{ Imports } & Natural gas & \multirow{3}{*}{$\begin{array}{l}\text { (Saint-Nazaire port authority, } \\
\text { 2016) }\end{array}$} & \multirow{3}{*}{2015} & \multirow{3}{*}{ None } \\
\hline & Crude oil & & & \\
\hline & Coal & & & \\
\hline & Uranium (for nuclear electricity) & (RTE, 2016) & 2015 & None \\
\hline & $\begin{array}{l}\text { Refined petroleum products (heavy fuel } \\
\text { oil, gasoline, diesel, kerosene, LPG) }\end{array}$ & $\begin{array}{l}\text { (Saint-Nazaire port authority, } \\
\text { 2016) }\end{array}$ & 2015 & None \\
\hline & Rape seeds (for biodiesel) & $\begin{array}{l}\text { (CARGILL, 2018; Saint- } \\
\text { Nazaire port authority, 2016) }\end{array}$ & 2015 & None \\
\hline & Biodiesel & $\begin{array}{l}\text { (Saint-Nazaire port authority, } \\
2016 \text { ) }\end{array}$ & 2015 & None \\
\hline & Wood & (ATLANBOIS, 2016) & 2015 & None \\
\hline \multirow{6}{*}{$\begin{array}{l}\text { Domestic } \\
\text { extraction } \\
\quad \text { and } \\
\text { production }\end{array}$} & Solar (thermal and photovoltaic) & (ENEDIS, 2015) & 2015 & None \\
\hline & Geothermal & \multirow{3}{*}{ (AXENNE, 2016) } & \multirow{3}{*}{2012} & None \\
\hline & Biogas & & & None \\
\hline & $\begin{array}{l}\text { Electricity from natural gas } \\
\text { (power plant) }\end{array}$ & & & None \\
\hline & $\begin{array}{l}\text { Refined petroleum products } \\
\text { (refinery) }\end{array}$ & $\begin{array}{c}\text { (TOTAL, 2013) } \\
\text { Shares of products in the total } \\
\text { production }\end{array}$ & 2013 & None \\
\hline & Biodiesel from rape oil & (AXENNE, 2016) & 2012 & None \\
\hline \multirow{4}{*}{$\begin{array}{l}\text { Total final } \\
\text { energy } \\
\text { consumption }\end{array}$} & Electricity (nuclear, wind, coal) & (ENEDIS, 2015) & 2015 & None \\
\hline & Heat (natural gas) & (GRDF, 2015) & 2015 & None \\
\hline & Heat (heavy fuel oil, coal, wood, steam) & (AXENNE, 2016) & 2012 & $\begin{array}{l}\text { Estimate for wood } \\
\text { based on the } \\
\text { increase in number } \\
\text { of dwellings } \\
\text { between } 2012 \text { and } \\
2015\end{array}$ \\
\hline & Transportation (fossil fuels, electricity) & (BASEMIS, 2015) & 2014 & $\begin{array}{l}\text { Estimate based on } \\
\text { the } 2015 \text { regional } \\
\text { consumption of } \\
\text { fossil fuels for } \\
\text { transportation }\end{array}$ \\
\hline \multirow{4}{*}{ Exports } & Municipal solid waste (incineration) & (AXENNE, 2016) & 2012 & None \\
\hline & Natural gas & \multirow{3}{*}{$\begin{array}{l}\text { (Saint-Nazaire port authority, } \\
\text { 2016) }\end{array}$} & \multirow{3}{*}{2015} & \multirow{3}{*}{ None } \\
\hline & Refined petroleum products & & & \\
\hline & Biofuels & & & \\
\hline
\end{tabular}

${ }^{1}$ The OPTIMISME research project (2016-2018) gathered CARENE's local authorities, professionals from the energy sector, industrials and researchers to develop appropriate tools to plan energy transition on the territory. 
221 As shown in Table 2, some data are older than 2015, such as the power plant's and biodiesel productions

222 (2012), the geothermal, biogas, wood, coal and fuel oil consumptions (2012) and the data from the

223 BASEMIS ${ }^{\circledR}$ database (2014). As much as possible, assumptions were made to adjust these

224 consumptions to the base year. For example, residential wood energy consumption was adjusted, taking

225 as the adjustment variable the number of new dwellings built between 2012 and 2015. The consumption

226 of petroleum products supplied by BASEMIS ${ }^{\circledR}$ was adapted to 2015 taking into account the 2014-2015

227 evolution of regional consumption of petrol and diesel for cars, light- and heavy-duty trucks. However,

228 the evolution of data related to industrial activities (energy production, coal and fuel oil consumptions)

229 depends on external variables related to fluctuations in domestic and global economic markets.

230 Therefore, it was not possible to derive a reliable approximate for 2015 and the values were not changed.

231 From interviews with municipal stakeholders in the frame of the OPTIMISME project, geothermal and

232 biogas consumptions did not evolve much between 2012 and 2015 and considering their low shares in

233 the total territorial consumption, it was decided not to change them. Another important assumption is

234 linked to the refinery's production. Indeed, it was impossible to determine with certainty what share of

235 the petroleum products' consumption came from the refinery's production, and what share was imported.

236 Therefore, it was assumed that the "domestic production/imports" breakdown for final consumption in

237 the territory was the same as the one for direct energy inputs, which was considered reasonable given

238 the black box nature of the refinery. Due to the lack of metadata for most sources, a calculation of

239 uncertainties was not possible.

240 3. Results

241

\subsection{External dependency of the CARENE's energy metabolism}

243 Results obtained from the spatial analysis of the CARENE's energy metabolism are presented on Figure

244 2. Figure 2 shows energy flows according to their type, their origin and destination markets. In particular, 245 the global, domestic and local levels are distinguished. The figure includes also energy losses resulting

246 from primary energy transformation and non-energy flows considered as co-products such as rapeseed

247 cakes and petrochemicals from the refinery. 


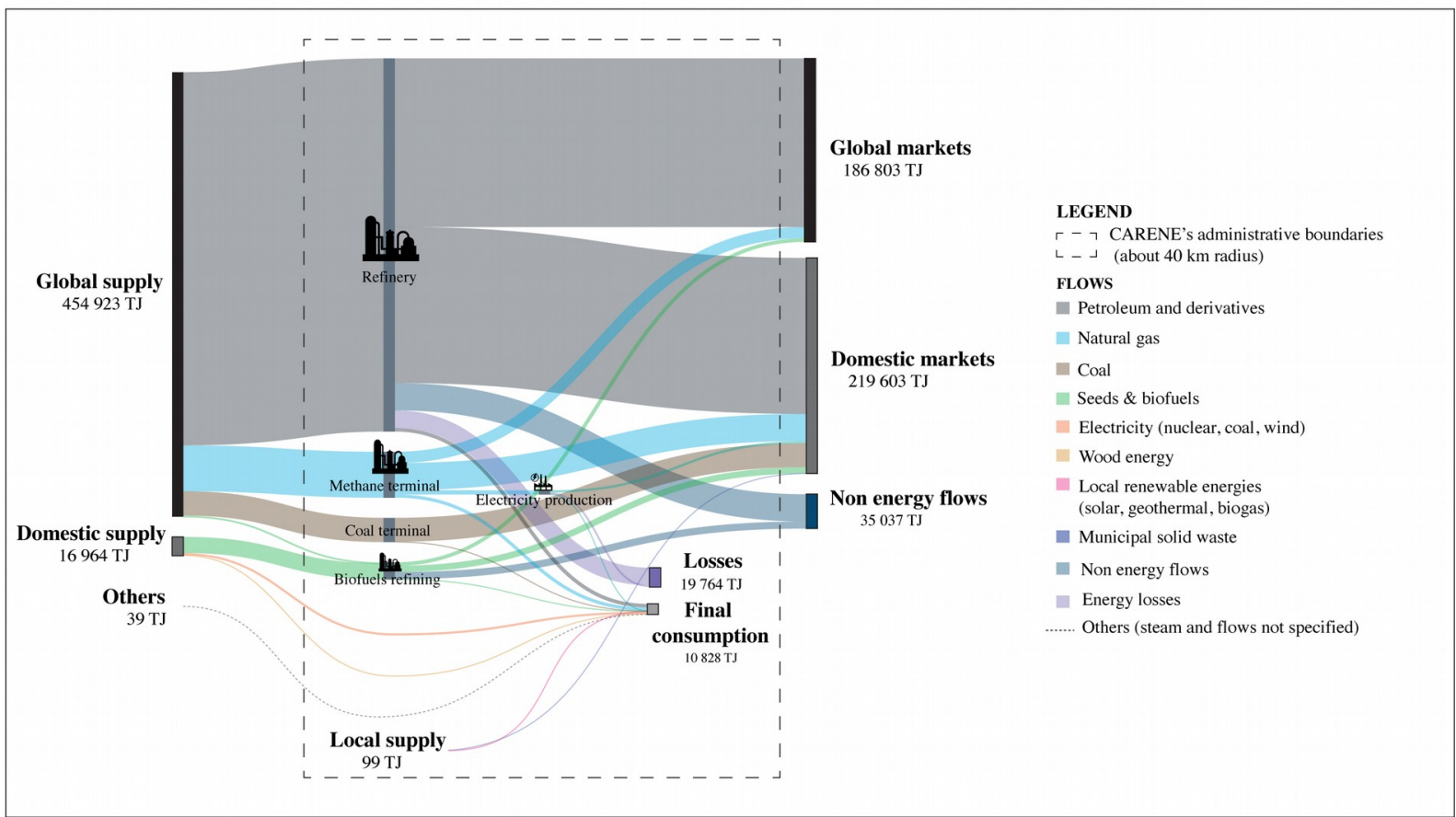

Figure 2: The CARENE's energy metabolism per type of energy flow in 2015 . The dashed line represents the territory's boundaries. (1.5 column)

The CARENE's energy metabolism is characterized by global transit flows, i.e. foreign imported flows that go through the CARENE but whose final destinations are outside of its boundaries. Transit flows are quite common for port areas, but the types of flows that transit depend on the specificity of each port (Rosado et al., 2016; Voskamp et al., 2017). In the CARENE's case, fossil fuels dominate widely in the form of petroleum and derivatives, natural gas and coal. It is worth noting that processing activities related to fossil fuels generates energy losses in the same order of magnitude than the territory's own energy consumption, reflecting thus the energy-intensive industrial activities of the area.

Two types of transit flows can be distinguished in Figure 2. Some are pure crossing flows and they are sometimes also called throughput flows (Voskamp et al., 2017). They do not undergo any transformation on the territory beside being transported. It is the case for imported petroleum products that transit through the refinery to domestic markets (62.6 PJ), for natural gas either transhipped from the methane terminal to other boats (11.5 PJ) or injected in the French distribution network (27.6 PJ), and for the coal transferred directly to the coal power plant located $30 \mathrm{~km}$ away from the Port (24.3 PJ). The second type of transit flows are processed on the territory to obtain different types of products or energy. Crude oil processed in the refinery to supply the northern parts of France from the West to the East and abroad is the main source of energy-related activities locally (269 PJ). Electricity obtained from the gas power plant is also a significant flow (2.5 PJ) even though this activity is more seasonal, to meet national peak energy demands during winter. 
Excluding crossing flows, the extent of the metabolism's dependency on resource-supplying hinterlands is reported in Table 3. Up to $96 \%$ of the total energy supply come from global sources, mainly due to

271 the refinery's activities. Local supply is almost inexistent and currently driven by the gas-fired power

272 plant's production. An interesting finding is the composition of the domestic supply, even though it

273 accounts for less than $5 \%$ of the total supply. Indeed, results show that most of the renewable energy

274 consumption is currently imported from neighbouring regions and not produced in the CARENE.

Table 3: External dependency rates for the CARENE's energy metabolism

\begin{tabular}{|r|l|l|l|}
\hline & \multicolumn{1}{|c|}{$\begin{array}{c}\text { Global } \\
\text { (without crossing flows) }\end{array}$} & \multicolumn{1}{c|}{ Domestic } & Local \\
\hline CARENE's dependency & $96 \%$ & $4 \%$ & $\approx 0.05 \%$ \\
\hline Weight of energy carriers on the dependency in the respective scale \\
\hline Petroleum and derivatives & $99.8 \%$ & - & - \\
\hline Natural gas & $<0.01 \%$ & - & - \\
\hline Coal & $0.1 \%$ & - & - \\
\hline Electricity (NR) & - & $19 \%$ & $83 \%$ \\
\hline Seeds \& biofuels & $0.1 \%$ & $78 \%$ & - \\
\hline Wood energy & - & $2 \%$ & - \\
\hline Wind electricity & - & $1 \%$ & - \\
\hline Solar electricity & - & - & $11 \%$ \\
\hline $\begin{array}{r}\text { Other renewables } \\
\text { (geothermal, biogas) }\end{array}$ & - & - & $6 \%$ \\
\hline
\end{tabular}

277 Figure 3 offers a more precise picture of supply distances at the domestic level. It shows that, on the

278 contrary of fossil fuels which come all from global trade, renewable energy carriers present a nuanced

279 picture. Biofuels' traffic tends to follow petroleum products, even though their hinterlands are mostly

280 domestic instead of foreign. Their production comes from rapeseeds (17.2 PJ), 82\% of which are

281 imported from farms in western and central France (within a radius of about $400 \mathrm{~km}$ ), the rest coming

282 from global sources. But this supply can be up to four times as distant as for other renewable energy

283 carriers, like wind $(100 \mathrm{~km})$ and wood $(150 \mathrm{~km})$. Only a neglectable fraction of renewable supply (solar,

284 geothermal, biogas) can be considered local $(<40 \mathrm{~km})$. 


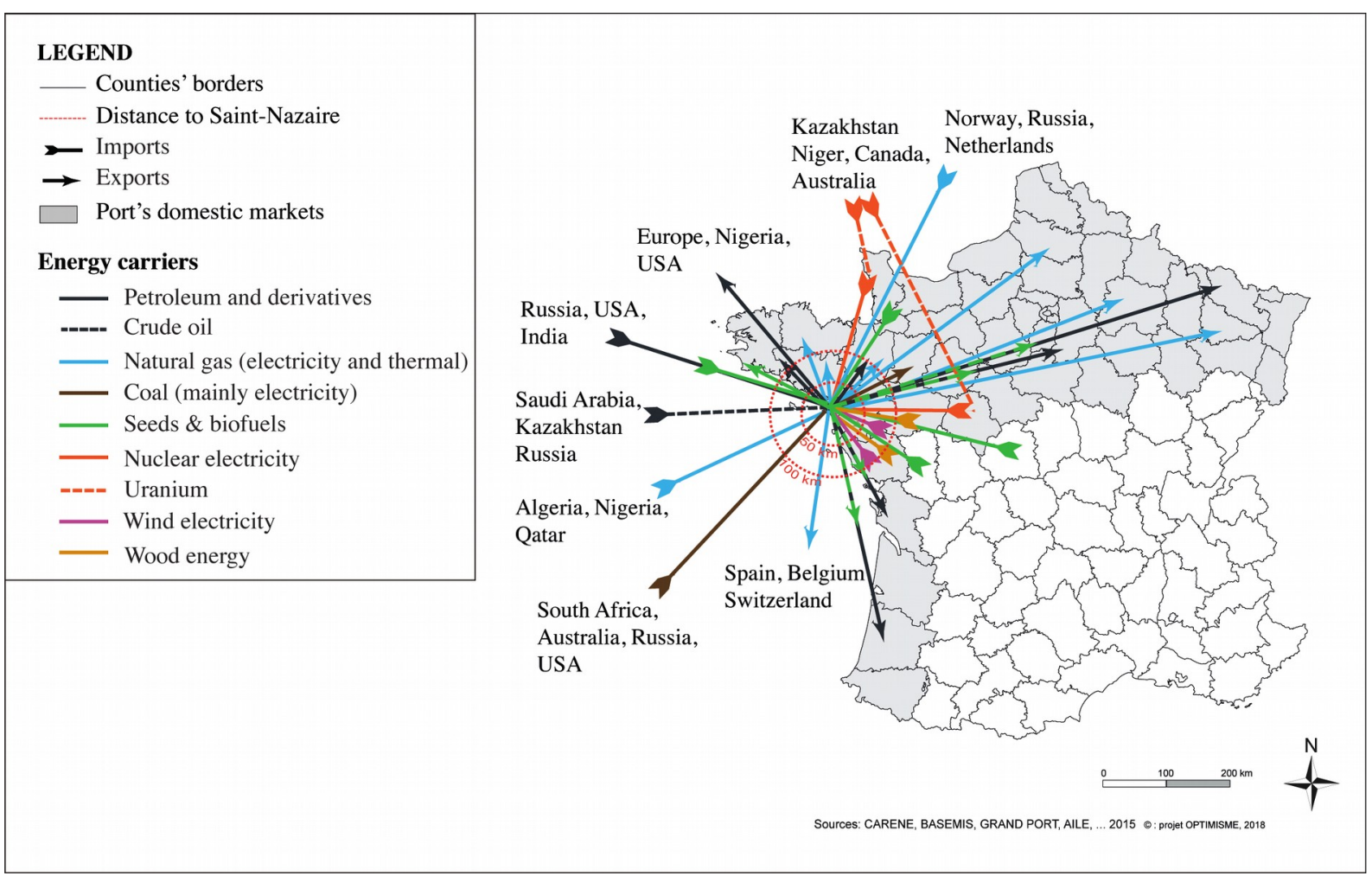

Figure 3: Energy supply areas and destinations markets by energy carrier (2015) (single column)

\subsection{Indirect energy flows}

Figure 4 presents the distribution across scales of indirect flows related to the CARENE's final energy consumption. As shown on the Figure, the primary energy supply amounts to a total of $15.7 \mathrm{PJ}$ to be compared with the total final energy consumption (TFEC), which is $10.8 \mathrm{PJ}$. This means that $4.9 \mathrm{PJ}$ of energy ( $45 \%$ of the TFEC) are lost along the supply chains owing to processing and transformation processes. While $94 \%$ of this primary energy come from foreign sources, reflecting the dependency illustrated in the last section, these losses occur mostly within the reach of French public authorities. This is explained by the structure of electricity production in France, which revolves around centralized nuclear power plants, of great capacity but which are also highly inefficient.

On the contrary, extraction and processing activities related to thermal heat flows (petroleum products, natural gas and coal) can be described as more energy efficient. Figure 3 shows that energy losses at the global and local scales, where all extraction and processing occur, is neglectable in comparison with electricity production. However, the amount of energy required to perform these activities, i.e. their embodied energy, is higher (per PJ produced) and mostly external to France. Results indicate that resources extraction, crude oil refining and natural gas processing occurring in foreign countries represent $91 \%$ of the embodied energy due to CARENE's TFEC, which amounts to 2.55 PJ (24\% of the TFEC). From a different perspective, only $3 \%$ of the total amount of embodied energy is found at the local scale and 6\% is domestic. Therefore, on the contrary of energy losses, embodied energy of supply chains is definitely a global challenge for cities, like it is for embodied carbon emissions (Chen and Zhu, 
2019; Wiedmann et al., 2016) and embodied land use (Steen-Olsen et al., 2012). This can only be resolved either through policies targeting footprint of upstream activities or with flows' substitution at the local level, through industrial symbiosis for example. This particular case will be discussed further in the section 4.2 .

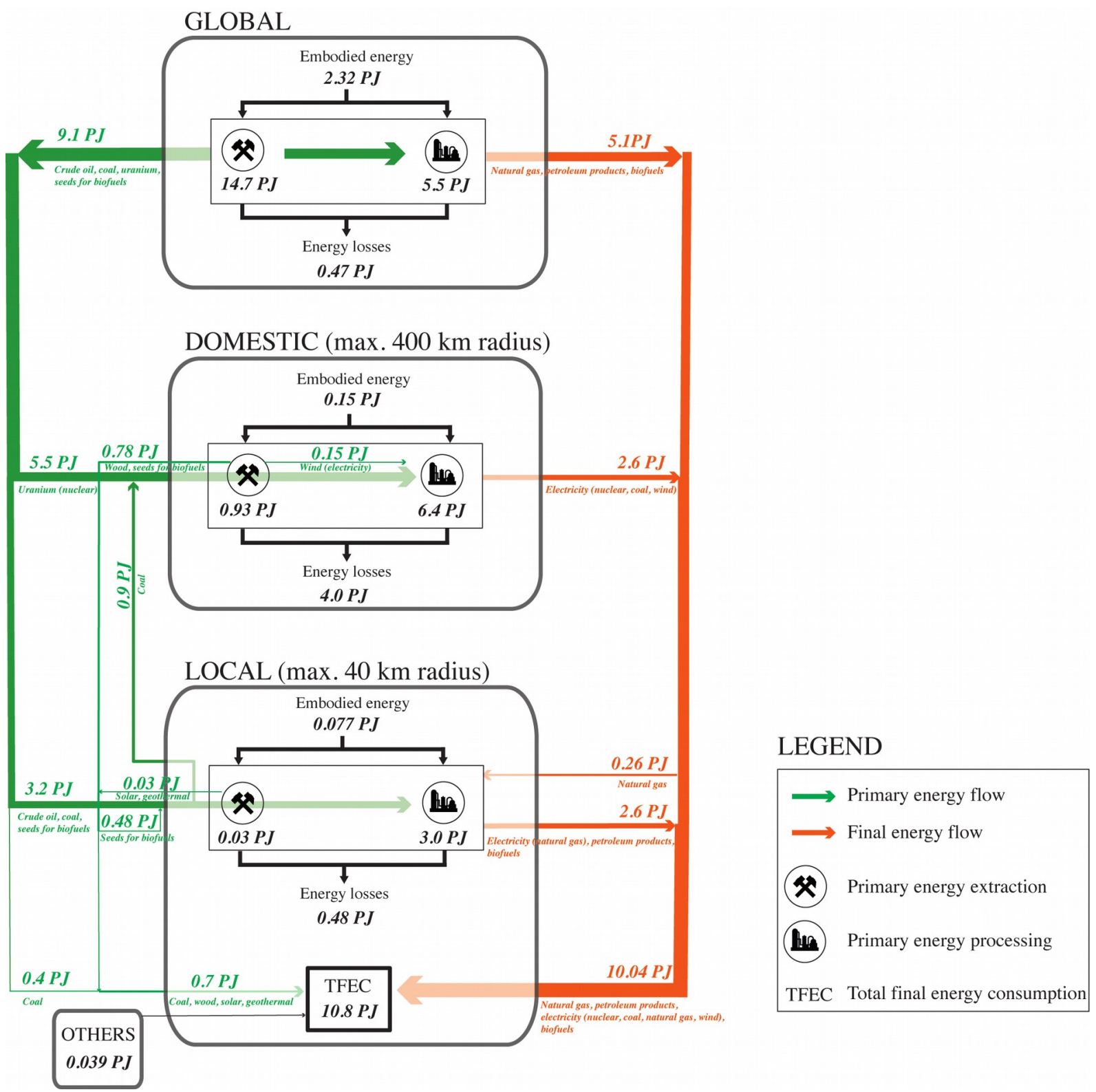

Figure 4: Multiscale analysis of indirect energy flows along the supply chains of CARENE's final energy consumption (double column)

\subsection{Comparison with previous studies}

315 Material and energy flow analysis has been applied to many cities and metropolitan areas over the last 316 two decades. Studies have been conducted on large cities, such as Paris (Barles, 2009; Kim and Barles, 317 2012), Stockholm (Rosado et al., 2016) and Singapore (Schulz, 2007), intermediate cities like Rennes 
and Le Mans in France (Bahers et al., 2018) and metropolitan areas like the Brussels Capital Region (Athanassiadis et al., 2016) and Los Angeles county (Ngo and Pataki, 2008). The metabolic profiles of several port-cities have also been analyzed including Amsterdam (Voskamp et al., 2017), Hamburg (Hammer et al., 2003), Gothenburg (Rosado et al., 2016) and Lisbon (Rosado et al., 2014).

Table 4 summarizes the results of some of them according to indicators relevant to this study. Case studies for the comparative analysis were selected based on data availability. In particular, the comparison with the CARENE is performed on imports and domestic extraction related to fossil fuels and renewable energies. Based on the aforementioned indicators, energy dependency to external hinterlands is estimated for each city. Finally, indirect flows are reported when possible, even though data on these indicators are scarce among MEFA studies. It should be noted that these results were obtained using different methodologies, especially for the Brussels Capital Region for which embodied energy of the area's energy use was estimated using a territory-based approach with IO tables (Athanassiadis et al., 2016).

Table 4: Indicators related to energy flows for different case studies

\begin{tabular}{|l|c|c|c|c|c|c|}
\hline & $\begin{array}{l}\text { CARENE } \\
(2015)\end{array}$ & $\begin{array}{l}\text { Amsterdam } \\
(2012)\end{array}$ & $\begin{array}{l}\text { Gothenburg } \\
(2011)\end{array}$ & $\begin{array}{l}\text { Stockholm } \\
(2011)\end{array}$ & $\begin{array}{l}\text { Paris } \\
(2003)\end{array}$ & $\begin{array}{l}\text { Brussels } \\
\text { Capital } \\
\text { Region } \\
(2007)\end{array}$ \\
\hline $\begin{array}{l}\text { Fossil fuels } \\
\text { imports* } \\
\text { (TJ/cap) }\end{array}$ & 2.7 & 0.51 & 0.47 & 0.06 & 0.08 & 0.06 \\
\hline $\begin{array}{l}\text { Renewable } \\
\text { energy imports } \\
\text { (TJ/cap) }\end{array}$ & 0.15 & 0 & Unknown & Unknown & Unknown & 0.001 \\
\hline $\begin{array}{l}\text { Industrial } \\
\text { production } \\
\text { (fossil fuels) } \\
\text { (TJ/cap) }\end{array}$ & 2.6 & Unknown & 0.33 & 0.07 & 0 & 0.003 \\
\hline $\begin{array}{l}\text { Renewable } \\
\text { energy } \\
\text { production } \\
\text { (TJ/cap) }\end{array}$ & 0.0026 & 0.0043 & Unknown & Unknown & Unknown & 0.0028 \\
\hline $\begin{array}{l}\text { Energy } \\
\text { dependency }\end{array}$ & $100 \%$ & $99 \%$ & $97 \%$ & $85 \%$ & Unknown & $95 \%$ \\
\hline $\begin{array}{l}\text { Losses } \\
\text { (TJ/TJ TFEC) }\end{array}$ & 0.46 & Unknown & Unknown & Unknown & 0.72 & Unknown \\
\hline $\begin{array}{l}\text { Embodied } \\
\text { energy } \\
\text { (TJ/TJ TFEC) }\end{array}$ & 0.24 & Unknown & Unknown & Unknown & Unknown & 2 \\
\hline
\end{tabular}

The Saint-Nazaire port imports five to six times more fossil fuels per capita than Amsterdam and Gothenburg, reflecting the energy-related nature of its industrial base, dominated by infrastructure specialized in the processing of energy flows (refinery, methane terminal, power plant). This appears 
also through the industrial production indicator, which is eight times higher than for Gothenburg. Renewable energy production on the other hand is far less developed than in the other case studies, including an industrial port-city like Amsterdam. Nevertheless, energy dependency to external hinterlands is similarly high between ports, which is expected due to their heavy reliance on fossil fuels for industrial activities. Stockholm and the Brussels Capital Region are slightly less energy dependent, even though the case of Brussels is close to Gothenburg's. The Brussels Capital Region imports indeed a significant part of its renewable energy consumption.

Finally, indirect energy flows could only be compared with Paris and Brussels due to a lack of accessible information. In particular, energy losses related to the Parisian energy use are 1.6 times higher than for the CARENE. This is quite consistent with the energy consumption profile of both areas presented in Table B.1 in the appendices, where Paris consumes more electricity coming from the national grid, hence more losses during transformation processes. Embodied energy related to energy use was found higher for the Brussels Capital Region. The comparison should be carried out carefully however due to different methodological choices mentioned previously. Embodied energy accounted in the Brussels' MEFA is more comprehensive because IO tables were used. The difference between the two values illustrates to some extent how embodied energy calculated in this work is probably underestimated.

\section{Discussion}

The current international energy context, which relies heavily on fossil fuels trade, favors dependency on remote hinterlands and high levels of embodied energy for industrialized cities like Saint-Nazaire. In a sense, the CARENE's energy metabolism is still a perfect representation of the past energy transition's outcome, that has led to the extension and centralization of the French national energy system (Kim and Barles, 2012). The current energy transition implies a spatial reorganization of this system, by proposing a diversification of primary energy sources. But the issues of dependency and indirect flows still remain. While alternative energy sources are not quite visible in the CARENE's metabolism yet, distinguishing different types of fossil and renewable energy flows helped to see the trends on how energy transition may spatially unfold for the territory. Some of the implications for dependency and indirect flows are discussed in this section.

\subsection{Dependency of port-cities in a transition context}

Port-cities are particularly threatened by the dependency to remote hinterlands since a significant part of their activities and revenues rely on foreign transit flows, whether they are just crossing the territory or processed and then exported. For example, a MFA study of Lisbon showed that crossing flows accounted for about 34\% of all material and energy inputs (Rosado et al., 2014). In Amsterdam, they represented $37 \%$ of the inputs for the year 2012 in average, but with a high heterogeneity depending on the types of flows considered (Voskamp et al., 2017). In the case of fossil fuels, $77 \%$ of the imports 
were just crossing while this share lowered to $30 \%$ for chemical products, suggesting that the Amsterdam's port is primarily an intermediary logistic hub for energy flows. In comparison, the CARENE's share of crossing flows is rather quite low (28\% of the energy imports), while transit flows that are processed within the area such as crude oil and natural gas constitute $58 \%$ of the inputs. These results show that Saint-Nazaire's port is more than a logistic hub and that its dependency to foreign hinterlands is closely linked to its core productive system. In order to reduce this dependence, it will be necessary to radically modify the economic model, along the lines of the transition started by some ports in Europe and Asia (Cerceau et al., 2014; Mat et al., 2016). A key strategy of this endeavour, albeit not the only one, is substituting fossil fuels processing with renewable energy production (Mat et al., 2016).

This particular strategy appears fundamental to ensure the resilience of the CARENE area (both for the port and the urban part) since results show that only $8 \%$ of the current renewable energy consumption are locally produced. Nowadays, without any renewable production from the port, most of the renewable energy supply comes from neighbouring regions (77\%), at the domestic level, suggesting that where renewable energy is concerned, dependency has not disappeared but has merely shifted scale. It will likely remain so as local energy autonomy is almost impossible to achieve for cities (Barles, 2019) and port areas have always been historically connected to their surrounding environment, even before their past transitions that led to globalization (Mat et al., 2016). Nevertheless, this relocation of energy supply and dependency does induce reinforced relationships between cities or regions that did not exist before and which must be identified. Some can lead to synergies and cooperation between a primary energy producer and a consumptive territory, e.g. wood supply from rural areas to cities. On the contrary, other cases can create conflictual power relations and competitions that may hamper the feasibility and sustainability of any energy transition plan (Bahers et al., 2020; Haberl et al., 2019). In the case of the CARENE, the conversion of the Cordemais' coal-fired power plant to a plant of a same size using combustion of green waste collected $200 \mathrm{~km}$ away is part of the national strategy to keep the infrastructure in place while finding alternative solutions. However, interviews with other energy producers, associations and local authorities highlighted that this decision threatens resources availability in the region, which may result in an actual decrease in the number of transition projects that could have been carried out by other stakeholders (Tanguy, 2019)

A multiscale analysis per type of energy flow helps to single out problematic energy carriers and the associated stakeholders by highlighting dependency issues. For example, in the CARENE's case, wood and biodiesel from rapeseed oil are to be watched closely. Wood is not indeed a resource that exists within the territory's boundaries, whereas it has a high substitution potential for residential natural gas use through district heating networks for example (AXENNE, 2016). Competitions for this resource may arise with other cities if such networks were to become more popular. This indicates that a regional coordination is required at the minimum for this resource. The biodiesel produced in Saint-Nazaire is already well integrated in the global and domestic markets, like its fossil counterparts. The risk to attract 
important and distant agricultural resources that may compete with other needs, like food, is therefore high. A relevant complementary solution, which is already considered by the Saint-Nazaire's port authority and should be further investigated, is third-generation biofuels produced from microalgae (Ahmad et al., 2011).

\subsection{Implications of a energy transition policy regarding indirect energy flows}

Results showed that accounting for indirect energy flows increased the CARENE's energy consumption by about $70 \%$. This means that for every MJ consumed within the area, $0.7 \mathrm{MJ}$ must be added in average to complete the quantitative energy balance. However, from a policy perspective, these additional 0.7 MJ are not homogeneous in type and space. Embodied energy (0.24 MJ) contributes to the environmental rucksack of the city whereas energy losses $(0.46 \mathrm{MJ})$ are energy waste, or excess heat, for the most part. It would be favorable if both were reduced but the second one can be recovered theoretically, through industrial or urban heating networks and thus be part of a local or national energy transition strategy. Therefore, managing indirect energy flows encompasses different types of policies and does not mean much if the flow type is not specified.

A noteworthy example of one policy that could potentially affect positively both types of indirect flows is the development of the aforementioned district/industrial heating networks. Such infrastructures are put at the forefront of energy transition in France by the law Transition Énergétique pour une Croissance Verte. This law sets the objective of a fivefold increase, by 2030, in the amount of heat from renewable and secondary sources distributed by heating networks (France Loi n²015-992, 2015). A number of secondary sources are possible, including heat from incinerators, data centers and, which is of interest here, from industrial activities. Just taking the CARENE's example, a heating network is being investigated within the port zone to deliver heat generated from industrial processes, which is currently released to the atmosphere, to industries and residents for their heating needs (GPMSN, 2014). This solution addresses a priori the generation of both energy losses and embodied energy: it finds a use for the losses and allows displacing a roughly equivalent amount of natural gas (in the CARENE's case).

However, one could wonder on the consequences of this decision further up the supply chain. Indeed, excess heat (energy losses) comes from thermal industrial processes relying on natural gas to operate. Building a fraction of the city's energy supply from excess heat may thus reinforce at the same time the use of natural gas to operate processes delivering this energy, which will just partly decrease the dependency on this resource. In the specific case of natural gas, it could even hamper efforts in reducing a major part of embodied energy consumed in foreign countries. Figure C.1 in the appendices shows for example that embodied energy associated with natural gas use constitutes the main source of embodied energy at the global scale. 
Future research involving comparison of different scenarios of excess heat integration in the territory's energy mix, with the calculations of related indirect flows, should be carried out to confirm this trend. While the conclusion drawn from this result should not discourage the implementation of excess heat recovery altogether, it certainly points out a limitation of this solution in the long-term objective of decreasing the territory's dependency and embodied energy. It is part of the debate between advocates of a "weak" and a "strong" energy transition (Duruisseau, 2014), the latter arguing, among other things, that punctual substitutions of fossil fuels, e.g. with excess heat, cannot be sufficient to allow the systems to remain and that only a major transformation of sociotechnical configurations is desirable (Raineau, 2011). Results obtained on the CARENE's metabolism tend to confirm that a radical change is indeed needed, and that projects including primary renewable energies such as wood, third-generation biofuels and solar energy, should be primarily investigated.

\section{Conclusions}

The objective of this work is to comprehensively address outsourcing issues in order to enhance their integration in urban metabolism studies. It contributes to the growing efforts in urban metabolism research to develop spatial approaches for flows' accounting, with the ultimate goal of better contextualizing urban policies' consequences at different scales (Athanassiadis et al., 2015; Bahers et al., 2018; Guibrunet et al., 2016; Huang et al., 2018). In this paper, a multiscale extended territory-based approach was developed, looking at both the dependency on external hinterlands and the generation of external hidden flows (embodied consumption and energy losses) due the city's demand in resources.

This approach was applied to the energy metabolism of the CARENE, a harbor-industrial area in France. Local sources accounted for less than $0.1 \%$ of the territory's energy inputs, domestic and global scales representing $4 \%$ and $96 \%$ of the supply respectively. More than pure transit activities, local refining of crude oil was found to drive this dependency on foreign hinterlands, suggesting that substituting fossil fuels processing with renewable energy production is a key strategy to ensure the resilience of the area, both from the port's and the city's perspective. However, results highlight that an energy transition with more low-carbon energy sources (wood, wind electricity, biofuels) will not necessarily reduce external dependency, but merely changes its scale from foreign to domestic. On the contrary of fossil fuels, supply of domestic renewable energy sources tends to present a nuanced picture, with varying supply distances among energy carriers, that ultimately influence at which scale the transition should be planned for each resource.

Analyses of indirect energy flows drew attention on natural gas and electricity's consumptions, main drivers of the supply chains' embodied energy and energy losses respectively. They put into perspective one transition policy in particular, which is the industrial excess heat recovery to feed industrial or 
district heating networks. Results suggest that, when the excess heat comes from natural gas, a trade-off exists between reducing the amount of embodied energy in foreign countries and using this local resource. While the conclusion drawn from this result should not discourage the implementation of excess heat recovery altogether, it certainly points out a limitation of this solution in the long-term objective of decreasing the territory's dependency and external embodied energy.

478 Future work is needed to go further into assessing the external consequences of energy policies across scales. For example, the multiscale approach presented in this paper could be used to carry out detailed scenario analyses of different energy transition policies in order to get a more comprehensive picture of the trade-offs outlined in this study, similar to what was done for food systems by Boyer and Ramaswami (2017). Recommendations for new policies should indeed consider the possible transfer of negative effects across scales and supply chains in order to formulate truly sustainable actions.

\section{Appendices}

\subsection{Appendice A}

Table A.1 presents the primary energy factors cumulative energy demand (CED) factors for several energy carriers. Following the IEA methodology on primary energy calculations (IEA, 2017), solar and wind become energy products at the point of electricity generation, which means the efficiency of solar and wind electricity production is not considered. CED factors for final energy carriers exclude CED factors of the corresponding primary energy carriers indicated in Table A.1.

Table A.1: Primary energy factors and non-renewable cumulative demand energy (CED) factors for several energy carriers

\begin{tabular}{|c|c|c|}
\hline Energy carrier & $\begin{array}{l}\text { Primary energy factors (MJ } \\
\text { primary energy/MJ final } \\
\text { energy) (Sims et al., 2007; } \\
\text { Wilby et al., 2014). }\end{array}$ & $\begin{array}{l}\text { Non-renewable CED factors (MJ/MJ } \\
\text { of energy carrier) (Frischknecht et } \\
\text { al., 2015) }\end{array}$ \\
\hline \multicolumn{3}{|l|}{ Primary energy } \\
\hline Coal & - & 0.013 \\
\hline Crude oil & - & 0.044 \\
\hline Uranium & - & 0.0077 \\
\hline Geothermal & - & 0.28 \\
\hline Rapeseeds & - & 0.39 \\
\hline Wood energy & - & 0.02 \\
\hline \multicolumn{3}{|l|}{ Final energy } \\
\hline Biodiesel & 1.7 & 0.11 \\
\hline $\begin{array}{r}\text { Electricity } \\
\text { (coal/gas/nuclear) }\end{array}$ & $3 / 1.7 / 3$ & $0.002 / 0.01 / 0.0001$ \\
\hline Natural gas (processed) & 1.08 & 0.53 \\
\hline
\end{tabular}


499

\begin{tabular}{|r|l|l|}
\hline Petroleum products & 1.06 & 0.014 \\
\hline Solar (photovoltaic) & 1 & 0.28 \\
\hline Wind (electricity) & 1 & 0.08 \\
\hline
\end{tabular}

\subsection{Appendice B}

Table B.1 presents the part of each primary energy source in the total energy requirements of Paris and the CARENE. The total energy requirements includes primary energy consumption and embodied energy flows. Indirect flows encompasses here primary energy losses and embodied energy.

Table B.1: Share of primary energy sources in the total energy requirements of Paris and the CARENE

\begin{tabular}{|c|c|c|}
\hline & $\begin{array}{l}\text { Paris (2006) from Kim \& Barles } \\
\text { (2012) }\end{array}$ & CARENE (2015) \\
\hline Primary energy sources & \multicolumn{2}{|c|}{ Shares in the total energy requirements $(\%)$} \\
\hline Nuclear & 44 & 31 \\
\hline Petroleum & 19 & 23 \\
\hline Natural gas & 24 & 33 \\
\hline Coal & 5 & 8 \\
\hline Biofuels & - & 2 \\
\hline Wind & - & 1 \\
\hline Wood & 0 & 2 \\
\hline Other renewables & 2 (hydraulic) & $\approx 0$ (solar, geothermal, biogas) \\
\hline Others & 6 & 1 \\
\hline
\end{tabular}

\subsection{Appendice $\mathrm{C}$}

Figure C.1 presents the distribution of indirect flows related to the CARENE's energy use across spatial scales. Natural gas extraction and processing are the main sources of embodied energy, while the conversion of nuclear energy to electricity causes the most energy losses. 


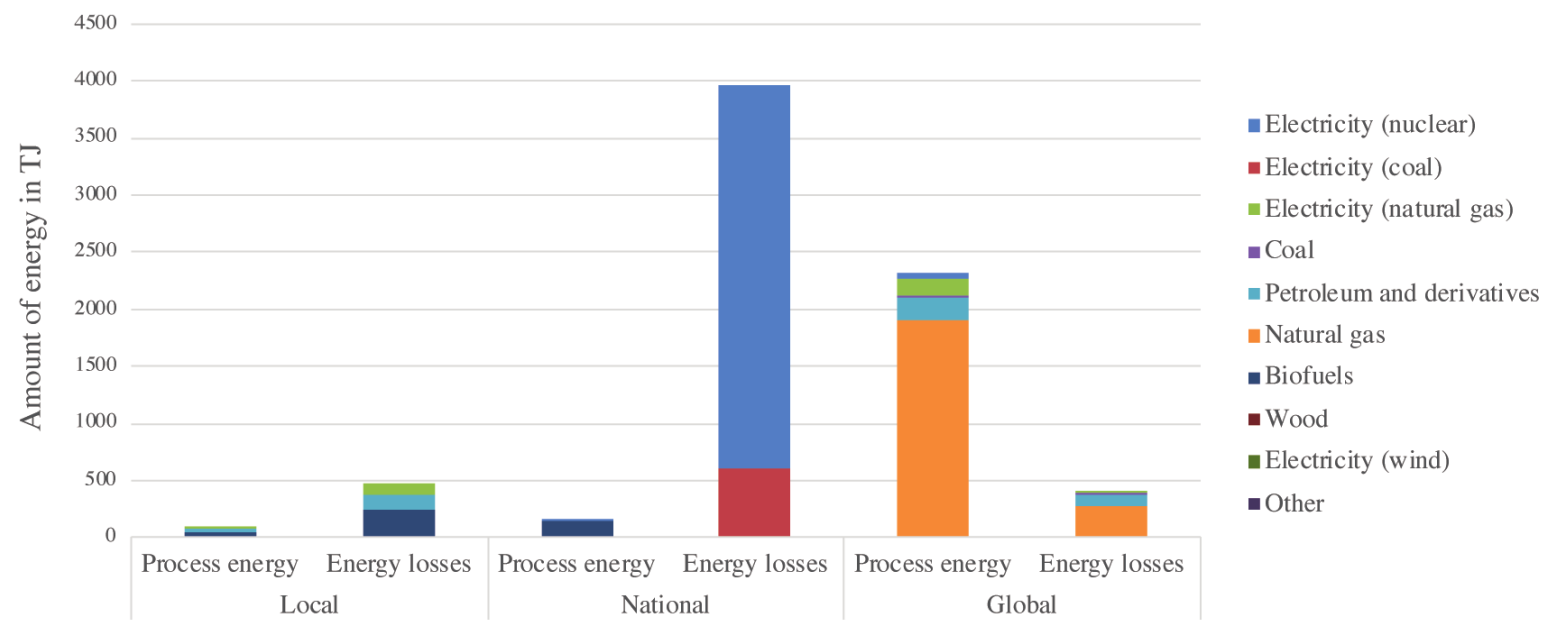

505

Figure C.1 : Amount of embodied energy and energy losses related to final consumption per scale and energy carrier

\section{Acknowledgements}

This research was funded by the French Agency for the Environment and Energy Management (ADEME) through its Energie Durable program. This work was part of the OPTIMISME project (20162018). The authors would like to thank all the project's partners, and especially the CARENE's administration and the Saint-Nazaire's port authority, who helped gathering data used in this paper.

\section{References}

Ahmad, A.L., Yasin, N.H.M., Derek, C.J.C., Lim, J.K., 2011. Microalgae as a sustainable energy source for biodiesel production: A review. Renew. Sustain. Energy Rev. 15, 584-593. https://doi.org/https://doi.org/10.1016/j.rser.2010.09.018

Athanassiadis, A., Christis, M., Bouillard, P., Vercalsteren, A., Crawford, R.H., Khan, A.Z., 2016. Comparing a territorial-based and a consumption-based approach to assess the local and global environmental performance of cities. J. Clean. Prod. 173, 112-123. https://doi.org/10.1016/j.jclepro.2016.10.068

Athanassiadis, A., Crawford, R.H., Bouillard, P., 2015. Overcoming the "black box" approach of urban metabolism 547-556.

ATLANBOIS, 2016. Principales données de la filière bois en Pays de la Loire.

AXENNE, 2016. Stratégie de développement des énergies renouvelables sur le territoire de la CARENE (Strategy for the development of renewable energies on Saint-Nazaire metropolitan area).

Bahers, J.-B., Barles, S., Durand, M., 2018. Urban Metabolism of Intermediate Cities: The Material Flow Analysis, Hinterlands and the Logistics-Hub Function of Rennes and Le Mans (France). J. Ind. Ecol. 0. https://doi.org/10.1111/jiec.12778

Bahers, J.-B., Tanguy, A., Pincetl, S., 2020. Metabolic relationships between cities and hinterland: a political-industrial ecology of energy metabolism of Saint-Nazaire metropolitan and port area (France). Ecol. Econ. 167, 106447. https://doi.org/https://doi.org/10.1016/j.ecolecon.2019.106447 
Balta-Ozkan, N., Watson, T., Mocca, E., 2015. Spatially uneven development and low carbon transitions: Insights from urban and regional planning. Energy Policy 85, 500-510. https://doi.org/https://doi.org/10.1016/j.enpol.2015.05.013

Barles, S., 2019. L'autonomie métabolique urbaine, un oxymore, une gageure?, in: Lopez, F., Pellegrino, M., Coutard, O. (Eds.), Les Territoires de l'autonomie Énergétique: Espaces, Échelles et Politiques. ISTE Editions Ltd, London.

Barles, S., 2009. Urban metabolism of Paris and its region. J. Ind. Ecol. 13, 898-913. https://doi.org/10.1111/j.1530-9290.2009.00169.x

Barles, S., Knoll, M., 2019. Long-term transitions, urban imprint and the construction of hinterlands, in: Soens, T., Schott, D., Toyka-Seid, M., De Munck, B. (Eds.), Urbanizing Nature: Actors and Agencies (Dis)Connecting Cities and Nature since 1500. Routledge, New York.

BASEMIS, 2015. Regional database of energy consumption and greenhouse gas emissions from Air Pays de la Loire.

Baynes, T.M., Wiedmann, T., 2012. General approaches for assessing urban environmental sustainability. Curr. Opin. Environ. Sustain. 4, 458-464. https://doi.org/https://doi.org/10.1016/j.cosust.2012.09.003

Billen, G., Barles, S., Garnier, J., Rouillard, J., Benoit, P., 2009. The food-print of Paris: long-term reconstruction of the nitrogen flows imported into the city from its rural hinterland. Reg. Environ. Chang. 9, 13-24. https://doi.org/10.1007/s10113-008-0051-y

Boyer, D., Ramaswami, A., 2017. What Is the Contribution of City-Scale Actions to the Overall Food System's Environmental Impacts?: Assessing Water, Greenhouse Gas, and Land Impacts of Future Urban Food Scenarios. Environ. Sci. Technol. 51, 12035-12045. https://doi.org/10.1021/acs.est.7b03176

Bridge, G., Bouzarovski, S., Bradshaw, M., Eyre, N., 2013. Geographies of energy transition: Space, place and the low-carbon economy. Energy Policy 53, 331-340. https://doi.org/10.1016/J.ENPOL.2012.10.066

CARGILL, 2018. Montoir-de-Bretagne [WWW Document]. URL https://www.cargill.fr/fr/montoirde-bretagne (accessed 4.11.18).

Cerceau, J., Mat, N., Junqua, G., Lin, L., Laforest, V., Gonzalez, C., 2014. Implementing industrial ecology in port cities: International overview of case studies and cross-case analysis. J. Clean. Prod. 74, 1-16. https://doi.org/10.1016/j.jclepro.2014.03.050

Chavez, A., Ramaswami, A., 2013. Articulating a trans-boundary infrastructure supply chain greenhouse gas emission footprint for cities: Mathematical relationships and policy relevance. Energy Policy 54, 376-384. https://doi.org/https://doi.org/10.1016/j.enpol.2012.10.037

Chen, G., Shan, Y., Hu, Y., Tong, K., Wiedmann, T., Ramaswami, A., Guan, D., Shi, L., Wang, Y., 2019. Review on City-Level Carbon Accounting. Environ. Sci. Technol. 53, 5545-5558. https://doi.org/10.1021/acs.est.8b07071

Chen, S., Long, H., Chen, B., Feng, K., Hubacek, K., 2020. Urban carbon footprints across scale: Important considerations for choosing system boundaries. Appl. Energy 259. https://doi.org/10.1016/j.apenergy.2019.114201

Chen, S., Zhu, F., 2019. Unveiling key drivers of urban embodied and controlled carbon footprints. Appl. Energy 235, 835-845. https://doi.org/https://doi.org/10.1016/j.apenergy.2018.11.018

Dittrich, M., Bringezu, S., Schütz, H., 2012. The physical dimension of international trade, part 2: 
Indirect global resource flows between 1962 and 2005. Ecol. Econ. 79, 32-43. https://doi.org/https://doi.org/10.1016/j.ecolecon.2012.04.014

DREAL, 2012. La situation des transports en Pays de la Loire (Transportation sector in the Pays de la Loire region).

DROPEC, 2016. Le profil énergie climat régional (energy and carbon regional profile) [WWW Document].

Duruisseau, K., 2014. L'émergence du concept de transition énergétique. Quels apports de la géographie? Bull. la Société géographique Liège 63, 21-34.

ENEDIS, 2015. Open database from the national electricity distributor (ENEDIS).

Eurostat, 2001. Economy-wide material flow accounts and derived indicators. A methodological guide. Luxembourg.

France Loi n²015-992, 2015. Loi n²015-992 du 17 août 2015 relative à la transition énergétique pour une croissance verte (in French).

Frischknecht, R., Wyss, F., Büsser Knöpfel, S., Balouktsi, M., 2015. Cumulative energy demand in LCA: the energy harvested approach. Int. J. Life Cycle Assess. 7, 957-960.

Galli, A., Wiedmann, T., Ercin, E., Knoblauch, D., Ewing, B., Giljum, S., 2012. Integrating Ecological, Carbon and Water footprint into a "Footprint Family" of indicators: Definition and role in tracking human pressure on the planet. Ecol. Indic. 16, 100-112. https://doi.org/10.1016/J.ECOLIND.2011.06.017

GPMSN, 2014. Démarche d'écologie industrielle (industrial ecology initiative).

GRDF, 2015. Open database from the national natural gas distributor (GRDF).

Guibrunet, L., Sanzana Calvet, M., Castán Broto, V., 2016. Flows, system boundaries and the politics of urban metabolism: Waste management in Mexico City and Santiago de Chile. Geoforum 85, 353-367. https://doi.org/10.1016/j.geoforum.2016.10.011

Haberl, H., Wiedenhofer, D., Pauliuk, S., Krausmann, F., Müller, D.B., Fischer-Kowalski, M., 2019. Contributions of sociometabolic research to sustainability science. Nat. Sustain. 2, 173-184. https://doi.org/10.1038/s41893-019-0225-2

Hammer, M., Giljum, S., Hinterberger, F., 2003. Material Flow Analysis of the City of Hamburg.

Hayashi, M., Hughes, L., 2013. The Fukushima nuclear accident and its effect on global energy security. Energy Policy 59, 102-111. https://doi.org/https://doi.org/10.1016/j.enpol.2012.11.046

Hillman, T., Ramaswami, A., 2010. Greenhouse Gas Emission Footprints and Energy Use Benchmarks for Eight U.S. Cities. Environ. Sci. Technol. 44, 1902-1910. https://doi.org/10.1021/es9024194

Hu, Y., Lin, J., Cui, S., Khanna, N.Z., 2016. Measuring Urban Carbon Footprint from Carbon Flows in the Global Supply Chain. Environ. Sci. Technol. 50, 6154-6163. https://doi.org/10.1021/acs.est.6b00985

Huang, C.-L., Vause, J., Ma, H.-W., Yu, C.-P., 2012. Using material/substance flow analysis to support sustainable development assessment: A literature review and outlook. Resour. Conserv. Recycl. 68, 104-116. https://doi.org/https://doi.org/10.1016/j.resconrec.2012.08.012

Huang, Q., Zheng, X., Liu, F., Hu, Y., Zuo, Y., 2018. Dynamic analysis method to open the "black box" of urban metabolism. Resour. Conserv. Recycl. 139, 377-386. 
https://doi.org/https://doi.org/10.1016/j.resconrec.2018.09.010

619

620

621

622

623

624

625

626

627

628

629

630

631

632

633

634

635

636

637

638

639

640

641

642

643

644

645

646

647

648

649

650

651

652

653

654

655

656

657

658

659

IEA, 2017. Understanding and using the Energy Balance [WWW Document]. URL $\mathrm{https}$ ://www.iea.org/commentaries/understanding-and-using-the-energy-balance (accessed 3.20.20).

INSEE, 2020. Primary energy [WWW Document]. Defin. methods Qual.

Jones, C.M., Kammen, D.M., 2011. Quantifying Carbon Footprint Reduction Opportunities for U.S. Households and Communities. Environ. Sci. Technol. 45, 4088-4095. https://doi.org/10.1021/es102221h

Kennedy, C., Cuddihy, J., Engel-yan, J., 2007. Metabolism of Cities. J. Ind. Tecnol. 11, 43-59.

Kennedy, C., Steinberger, J., Gasson, B., Hansen, Y., Hillman, T., Havránek, M., Pataki, D., Phdungsilp, A., Ramaswami, A., Mendez, G.V., 2009. Greenhouse Gas Emissions from Global Cities. Environ. Sci. Technol. 43, 7297-7302. https://doi.org/10.1021/es900213p

Kim, E., Barles, S., 2012. The energy consumption of Paris and its supply areas from the eighteenth century to the present. Reg. Environ. Chang. 12, 295-310. https://doi.org/10.1007/s10113-0110275-0

Krausmann, F., 2013. A city and its hinterland: Vienna's energy metabolism 1800-2006, in: Singh, S.J., Haberl, H., Chertow, M., Mirtl, M., Schmid, M. (Eds.), Long Term Socio-Ecological Research: Studies in Society-Nature Interactions Across Spatial and Temporal Scales. Springer Science, pp. 1-588. https://doi.org/10.1007/978-94-007-1177-8

Larsen, H.N., Hertwich, E.G., 2010. Identifying important characteristics of municipal carbon footprints. Ecol. Econ. 70, 60-66. https://doi.org/https://doi.org/10.1016/j.ecolecon.2010.05.001

Lenzen, M., Peters, G.M., 2010. How City Dwellers Affect Their Resource Hinterland. J. Ind. Ecol. 14, 73-90. https://doi.org/10.1111/j.1530-9290.2009.00190.x

Lin, J., Hu, Y., Cui, S., Kang, J., Ramaswami, A., 2015. Tracking urban carbon footprints from production and consumption perspectives. Environ. Res. Lett. 10. https://doi.org/10.1088/17489326/10/5/054001

Lin, J., Liu, Y., Meng, F., Cui, S., Xu, L., 2013. Using hybrid method to evaluate carbon footprint of Xiamen City, China. Energy Policy 58, 220-227. https://doi.org/https://doi.org/10.1016/j.enpol.2013.03.007

Lin, T., Yu, Y., Bai, X., Feng, L., Wang, J., 2013. Greenhouse Gas Emissions Accounting of Urban Residential Consumption: A Household Survey Based Approach. PLoS One 8. https://doi.org/10.1371/journal.pone.0055642

Liu, G., Müller, D.B., 2013. Mapping the Global Journey of Anthropogenic Aluminum: A TradeLinked Multilevel Material Flow Analysis. Environ. Sci. Technol. 47, 11873-11881. https://doi.org/10.1021/es4024404

Mancini, L., Benini, L., Sala, S., 2015. Resource footprint of Europe: Complementarity of material flow analysis and life cycle assessment for policy support. Environ. Sci. Policy 54, 367-376. https://doi.org/https://doi.org/10.1016/j.envsci.2015.07.025

Mat, N., Cerceau, J., Shi, L., Park, H.S., Junqua, G., Lopez-Ferber, M., 2016. Socio-ecological transitions toward low-carbon port cities: Trends, changes and adaptation processes in Asia and Europe. J. Clean. Prod. 114, 362-375. https://doi.org/10.1016/j.jclepro.2015.04.058

Minx, J., Baiocchi, G., Wiedmann, T., Barrett, J., Creutzig, F., Feng, K., Förster, M., Pichler, P.P., 
Weisz, H., Hubacek, K., 2013. Carbon footprints of cities and other human settlements in the UK. Environ. Res. Lett. 8. https://doi.org/10.1088/1748-9326/8/3/035039

Ngo, N.S., Pataki, D.E., 2008. The energy and mass balance of Los Angeles County. Urban Ecosyst. 11, 121-139. https://doi.org/10.1007/s11252-008-0051-1

Raineau, L., 2011. Vers une transition énergétique? Natures Sci. Sociétés 19, 133-143.

Ramaswami, A., Chavez, A., Ewing-Thiel, J., Reeve, K.E., 2011. Two Approaches to Greenhouse Gas Emissions Foot-Printing at the City Scale. Environ. Sci. Technol. 45, 4205-4206. https://doi.org/10.1021/es201166n

Ramaswami, A., Hillman, T., Janson, B., Reiner, M., Thomas, G., 2008. A Demand-Centered, Hybrid Life-Cycle Methodology for City-Scale Greenhouse Gas Inventories. Environ. Sci. Technol. 42, 6455-6461. https://doi.org/10.1021/es702992q

Rosado, L., Kalmykova, Y., Patrício, J., 2016. Urban metabolism profiles. An empirical analysis of the material flow characteristics of three metropolitan areas in Sweden. J. Clean. Prod. 126, 206217. https://doi.org/https://doi.org/10.1016/j.jclepro.2016.02.139

Rosado, L., Niza, S., Ferrão, P., 2014. A Material Flow Accounting Case Study of the Lisbon Metropolitan Area using the Urban Metabolism Analyst Model. J. Ind. Ecol. 18, 84-101. https://doi.org/10.1111/jiec.12083

Rosales Carreón, J., Worrell, E., 2018. Urban energy systems within the transition to sustainable development. A research agenda for urban metabolism. Resour. Conserv. Recycl. 132, 258-266. https://doi.org/10.1016/J.RESCONREC.2017.08.004

RTE, 2016. Bilans électriques et perspectives - Pays de la Loire (Electricity assessment and perspectives - Pays de la Loire region).

Saint-Nazaire port authority, 2016. Suivi des vracs solides et liquides importés et exportés (Account on solids and liquids products imported and exported) - Base year 2015.

Schulz, N.B., 2007. The Direct Material Inputs into Singapore' s Development. J. Ind. Ecol. 11, 117131. https://doi.org/10.1162/jie.2007.1200

Sims, R.E.., Schock, R.N., Adegbululgbe, A., Fenhann, J., Konstantinaviciute, I., Moomaw, W., Nimir, H.., Schlamadinger, B., Torres-Martinez, J., Turner, C., Uchiyama, Y., Vuori, S.J.., Wamukonya, N., Zhang, X., 2007. Energy Supply, in: Metz, B., Davidson, O.R., Bosch, P.R., Dave, R., Meyer, L.A. (Eds.), Climate Change 2007: Mitigation. Contribution of Working Group III to the Fourth Assessment Report of the Intergovernmental Panel on Climate Change. Cambridge University Press, Cambridge, United Kingdom and New York, NY, USA.

Steen-Olsen, K., Weinzettel, J., Cranston, G., Ercin, A.E., Hertwich, E.G., 2012. Carbon, Land, and Water Footprint Accounts for the European Union: Consumption, Production, and Displacements through International Trade. Environ. Sci. Technol. 46, 10883-10891. https://doi.org/10.1021/es301949t

Tanguy, A., 2019. Le rôle des compétitions territoriales dans la transition énergétique. Flux 116-117, 176-191. https://doi.org/10.3917/flux1.116.0176

TOTAL, 2013. La plateforme de Donges - Un site industriel majeur de l'estuaire de la Loire (The Donges plateform - A major industrial site of the Loire's estuary) [WWW Document]. URL http://www.ufip.fr/uploads/img/A0.pdf

Verrastro, F., Ladislaw, S., 2007. Providing energy security in an interdependent world. Wash. Q. 30, 95-104. https://doi.org/10.1162/wash.2007.30.4.95 
Voskamp, I.M., Stremke, S., Spiller, M., Perrotti, D., van der Hoek, J.P., Rijnaarts, H.H.M., 2017. Enhanced Performance of the Eurostat Method for Comprehensive Assessment of Urban Metabolism: A Material Flow Analysis of Amsterdam. J. Ind. Ecol. 21, 887-902. https://doi.org/10.1111/jiec.12461

Wiedmann, T.O., Chen, G., Barrett, J., 2016. The Concept of City Carbon Maps: A Case Study of Melbourne, Australia. J. Ind. Ecol. 20, 676-691. https://doi.org/10.1111/jiec.12346

Wiedmann, T.O., Schandl, H., Lenzen, M., Moran, D., Suh, S., West, J., Kanemoto, K., 2015. The material footprint of nations. Proc. Natl. Acad. Sci. U. S. A. 112, 6271-6276. https://doi.org/10.1073/pnas.1220362110

Wilby, M.R., Rodríguez González, A.B., Vinagre Díaz, J.J., 2014. Empirical and dynamic primary energy factors. Energy 73, 771-779. https://doi.org/https://doi.org/10.1016/j.energy.2014.06.083

Zhang, C., Chen, W.-Q., Ruth, M., 2018. Measuring material efficiency: A review of the historical evolution of indicators, methodologies and findings. Resour. Conserv. Recycl. 132, 79-92. https://doi.org/https://doi.org/10.1016/j.resconrec.2018.01.028

Zheng, H., Wang, X., Li, M., Zhang, Y., Fan, Y., 2018. Interregional trade among regions of urban energy metabolism: A case study between Beijing-Tianjin-Hebei and others in China. Resour. Conserv. Recycl. 132, 339-351. https://doi.org/https://doi.org/10.1016/j.resconrec.2017.05.010 